\title{
The Quality of Housing Produced by the Low Income in a Developing Country: A case study in Ibadan, Nigeria
}

\author{
Jaiyeoba Babatunde Emmanuel \\ Department of Architecture, Faculty of Environmental Design and Management, \\ Obafemi Awolowo University, lle Ife, Nigeria \\ tundejaiyeoba@yahoo.co.uk
}

\begin{abstract}
The paper illustrates how housing produced by the low income in Ogbere area of Ibadan is negotiated from the societal complex due to the inability of government to provide for them and lowincome housing not being attractive to the profit driven private sector. Quantitative and qualitative methods were adopted while using the lens of Lefebvre's theory of space to examine the people, the process and the houses produced. The findings necessitate situating low income housing standards, quality and policy interventions in the social context to upgrade the quality of life in urban areas.
\end{abstract}

Keywords: Lefebvre, Low income, Housing production, Social context

eISSN 2514-751X @ 2018. The Authors. Published for AMER ABRA cE-Bs by e-International Publishing House, Ltd., UK. This is an open access article under the CC BY-NC-ND license (http://creativecommons.org/licenses/bync-nd/4.0/). Peer-review under responsibility of AMER (Association of Malaysian Environment-Behaviour Researchers), ABRA (Association of Behavioural Researchers on Asians) and cE-Bs (Centre for EnvironmentBehaviour Studies), Faculty of Architecture, Planning \& Surveying, Universiti Teknologi MARA, Malaysia.

DOI: https://doi.org/10.21834/aje-bs.v3i7.266 


\subsection{Introduction}

Poverty and housing poverty is one of the greatest problems to the quality of life in urban areas. Processes of achieving quality of life are related to the process of achieving sustainable development which aims to improve the welfare and happiness of all citizens (Roberts, 2000). The societal triangular formation means that the quantitative need for housing by the low income is enormous and meeting this need is one step to improving the quality of life in urban areas. In the developing world including Nigeria, meeting this need has become a herculean task considering the available statistics. "Currently over $90 \%$ of Nigerians in low income bracket cannot afford decent accommodation even if they saved 100\% of their incomefor 10 years" (quote in Awofeso, 2010). Also, according to the financial system strategy 2020 International conference, Nigeria with a housing stock of 10.7 million units has a housing shortfall of between 12 million and 16 million units. This housing shortfall is caused by rapid urbanization due to the gradient of development between rural and urban areas. In an environment of competition for the limited available resources overburdened by recurrent expenditure and mismanagement in a developing economy, housing scarcity is inevitable. Incentives for housing provision like mortgage and financing facilities are also scarce. Available finance is at double digit interest rate which is not attractive even to the high income. In fact, only $5 \%$ of the housing stock is in formal mortgage. This prevailing social context has not shown any sign of changing. In this harsh context, low income people continue to produce houses in the absence of state aid or institutional support. The housing produced has varied qualities. They are products of the negotiation of the low income in the social context through everyday forms of resistance. This housing quality in spite of the perception by others is socially produced. The study deploys Henri Lefebvre's theory of space to understand how the poor arrive at the housing quality they attained in the urban context despite their social, economic and political exclusion.

\subsection{Literature Review}

The discussion on quality of life in the urban environment regard most houses produced by the poor as slums, and their portion of urban space as predominantly illegal or squatter settlements as widely studied in Latin America. The importance of housing and how it separates people into groups needs no further elaboration. What is not appreciated is how the lack of attention to the housing situation of the majority lowers the aggregate or mean quality of life. City authorities and other income groups must know that low income people are normal human beings who are part of the city system (Boonyabancha, 2005). The size, quality and cost of housing is a key element of household consumption, social inequality and household chances (Hammett, 1995 in Silva \& Wright, 2009). Politicians and public policy experts that are empowered by the people are most prone to the negative perception of low income housing and the producers. The fluidity in the definitions of slums, squatter settlements, and the homeless reflects this perception. Evictions and clearance without recourse to human well-being, satisfaction and happiness is a minus to the quality of life in the urban environment. In the literature, professional and higher social class perceptions, persuasions and expectations dominate discussions and arguments on housing standards 
to improve the overall quality of life. Many of these arguments are done outside the social context and without the participation of low income people. In fact, public policy can only control standards if there are enough resources to provide the variety of houses needed by everyone in the city. A viewpoint therefore advocates socially acceptable standards that are permanently redefined in the context of an ongoing social struggle for low income housing (Ramirez et al in Walker, 2001).

Many gaps are obvious in low income housing studies. These include; what are the socially acceptable standards to low income people in different contexts, and what do they contend with in defining and redefining these standards. Others are; what are their weapons in the struggle and negotiation for housing, and how do they continue to build especially in legal and semi-legal ways against all odds. Lefebvre's social theory of space provide insights into how any portion of space including the built environment to which housing is a subset is transformed by human agency from absolute space through abstract space to differential space (Lefebvre, 1976). These transformations involve contests withineverydaylife practices. The derived concept is that low income housing, a subset of the built environment is a differential space. It is a product of the struggles of the poor to attain housing in the abstract environment in which they are the lowest in the ladder. Lefebvre contends that the separation of form, function and structure, a subsystem of the everyday in the rationalization of the habitat has guided much of planning practice since the $20^{\text {th }}$ century resulted in reductionist approaches (Butler, 2003). Butler (2003) also infer from Lefebvre that functionalism allows dividing urban areas into strict land uses and zones of different housing density occupied by different segments of the society, while formalism deploys the logic of visualization (aesthetics) for imposing master planning techniques and urban design to the social reality of low income housing. This also accounts for governments encouraging entrepreneurs to undertake large housing projects and indirectly subsidise the projects by making services and infrastructure available to them at sub-market rates (Gleeson\& Low, 2000). For Lefebvre, it is the rationality of the habitat that necessitates an authoritarian technical and scientific expertise over the democratic control of space. Lefebvre (1996) in 'right to the city' posited that cities are made up of diverse groups of individuals who all seek the right to participate, play, create and live in urban spaces. Structuralism seeks to isolate different issues and exclude other elements from the analysis, for example, product and process approaches that restrict low income housing studies to materials, technology, economic, financial or political issues and combinations thereof. "The fragmentation and compartmentalization of the human sciences only contributes to a theoretical ignorance of the social totality and the unity of knowledge and reality", (Lefebvre, 1968 in Butler, 2003). Lefebvre contends that space, including the different aspects of it is produced and that when human beings are involved it is transformed to social space - where space is both lived and produced (Lefebvre, 1976, 1991). Low income housing is socially produced and the quality socially attained. InaLefebvriananalysis, abstract space of representations of public authorities need more understanding and recognition of the spatial practices in representational spaces (low income settlements). This is necessary to arrive at appropriate housing quality policies to elevate the quality of life in urban environments. An understanding of how low income people produce and reproduce 
housing should proceed from the total to the particular and over an extremely wide range of social phenomena. This illuminates how the housing quality attained is negotiated from the social context.

\subsection{Methodology}

This study is contextual and adopts a case study approach to x-ray and provide abetter understanding of the history and status of the human agency, the processes they adopt, the typologies and different stages of the product; and the various struggles, negotiations and trade-offs that take place in the socio-economic, cultural and political environment. The formal and informal role and involvement of related human agency- friends, family, community, professionals and non-professionals (private and institutional) - is examined to adequately explain low income housing. The struggles of the low income in the societal complex and how these produce social relations, a significant input into low income housing is studied. This necessitates considering low income housing as one of the spatial practices of everyday life of poor people. This is necessary to balance aspects of reality normally ignored or missed out by specialists.

The study adopted Ogbere area, one of the low income settlements on the outskirts of Ibadan, the then largest city in West Africa as a case study to allow for intensive explanation and description. The area is between latitude $8.125 \mathrm{~N}$ and $8.15 \mathrm{~N}$ and longitude $6.035 \mathrm{E}$ and 6.045E enclosing approximately 2005 buildings in a rectangular area of about one square $\mathrm{km}$. Quantitative and Qualitative data were collected from half (1003) of the housing producers and their houses; the first house was randomly chosen, and every other house was taken. Multiple techniques of questionnaires administered as interview schedule, in-depth interview of 25 willing informants among the producers and observation was used. Qualitative data obtained by observation and interview included spatial organization, the physical characteristics, degree and level of completeness, materials and technology, available services and facilities. Data collected were analyzed quantitatively using frequency distribution analyses, cross tabular descriptive analyses, discriminant classification analyses and categorical regression that allowed for optimal scaling of variables on SPSS 16.0. The qualitative data were subjected to content analysis.

\subsection{Results and Discussions}

The housing quality attained in the Ogbere representational space is the product of the 'lived' experience of many years of struggle and negotiation considering that more than half $(54.7 \%)$ were between 56 and 70 years old and $28.7 \%$ were between 41 and 55 years. The youngest 'spatial practitioners' aged 26 to 40 years constituted only $4.3 \%$. Actually the odds of being an owner occupier increase between 26 and 70 years and thereafter decreases. This quality may have been unattainable but for their pride to have a self-owned house which is at the top of the motivation for housing production. Most lived in family houses as children (67.2\%) with parents and $28.1 \%$ as adults. Motivation for house ownership was passed on as indigenous knowledge from the elderly to the younger ones. Many believe that they have a 
'culture' of house ownership, one said: "i started in my family house at Oje (in the old core of Ibadan) with my father and later with my uncle at the age of twenty before I joined the army; my uncle who was a teacher also built a house in which I also stayed briefly". This pride motivated $32.6 \%$; the desire for comfort, convenience and privacy motivated $24.9 \%$, while the desire 'to become a man' and take care of the immediate and future needs of the wife or wives and children drove $13.3 \%$ into housing production. The usual 'basic shelter' reasons given for low income housing production such as to avoid paying rent $(9.3 \%)$, landlord harassment, housing crisis after loss of spouse (5.4\%) and generating rent or as investment $(2.4 \%)$ were not the major motivating factors. A significant $75.4 \%$ earlier lived in the old core of the city. In this old core of the city where many lived in the family houses, the spatial practitioners developed substantial bonding social capital through family networks that in turn increased the 'friends' that aided various negotiations of different stages of the housing production process (Jaiyeoba, 2011)

The spatial practitioners claimed their portion of the Ibadan Urban space in Ogbere through the social network of 'friends' they developed in family houses and their everyday, especially in informal occupation in which $82.2 \%$ of them were involved. The predominant size of plot for a house was between $450 \mathrm{~m}^{2}$ and $650 \mathrm{~m}^{2}$ which constituted $61.7 \%$ of the plots or slight variations of the 'standard' sizes (14.5\%). Also, most of the boundaries were not firm because only $10.4 \%$ of the plots were fenced or marked in any other way. The buildings more or less occupied the boundaries of the plot. The public authorities' representations of space idea of standardised plots and standardised setbacks and air space would have prevented those with 'half plots' from housing production; homogeneity is difficult when human beings socially produce space. There always exist a dialectical contradiction of the Lefebvrian differential space or representational space, and space of representations of abstract space (urban authorities). Though most are indigenes, they still bought the land through intermediaries or 'friends' in semi-legal ways, that are well known even to the authorities considering the number that thought they had legalised their building $(66.7 \%)$ by having a local government planning authority approval. The 'abstract space' (government and public authorities) expect them to have a certificate of occupancy or deed of assignment signed by the Governor of the State who is constitutionally empowered to allocate all land. The real process and administrative cost of doing this is outside the reach of low income people; rather, they would negotiate this by physical occupation of the land which they believe constitute establishing ownership. The plans were drawn by 'draughtsmen' in $56.7 \%$ of the cases, with a claim that $19.5 \%$ got an architect to produce the plan. It is a claim because both terms were used interchangeably for the 'plan drawer'. Plans were obtained from a friend by $13.7 \%$ of them or from the mason or 'bricklayer' by $4.4 \%$ of the housing producers. The interview sessions revealed that many of the Ogbere residents believe professionals are not interested in operating at their level. Also, they believe that workers of planning authorities are there to help them with everything including design and supervision. Most of the participants in the process were 'friends' of the nuclear and extended family and the social network of the producer. 
The typical house in Ogbere (90.1\%) was a rectangular, one level rooming house consisting of mainly rooms and a common entertainment space 'parlour' on either side of a linear passage. Even number of rooms especially the 6 room (41.1\%) and the 8 room $(38.2 \%)$ were the most common. It appears that what low income people need most are rooms. The 'abstract space' idea of professionals is to provide 'ready-made' complete buildings with separate living room, dining room, kitchen, store, and a number of rooms directly proportional to the income class of the expected user with a corresponding number of bathrooms/toilets. This is presumptuous and undemocratic considering the findings in the Ogbere representational space. The service facilities - toilet, bathroom and kitchen were mostly located at the back of the house; within and without, shared and scarcely more than 1 or 2 . The pit latrine located internally $(34.3 \%)$ or externally $(19.7 \%)$ is the most common toilet type while $17.8 \%$ had no toilet facility. The one bathroom house whether internally $(36.4 \%)$ or externally (14.7\%) was also the most common. Figure 1 and Figure 2 show the location of services in the building and on the site.

More than half of the houses $(54.4 \%)$ had one $(35 \%)$ or two $(19.3 \%)$ kitchens internally while an additional $13.8 \%$ had one $(12.1 \%)$ or two $(1.7 \%)$ externally located cooking space. The incidence of cooking in the backyard, the space in between sleeping rooms and toilet and bathroom spaces, the central corridor/passage in between the rooms or even in the room was common. Low income neighbourhoods are known to have little or no presence of government facilities, the Ogbere area is no exception. The residents are mostly dependent on shallow $(23.7 \%)$ or deep wells/borehole (1.5\%) for water supply; nine houses (1\%) had public water supply.

The discrepancy between the observed presence of electrical supply to the houses and the answer to whether the houses had electrical supply was high perhaps indicating the differential between legal and illegal connections to the public supply. Only $2.3 \%$ voluntarily indicated they had public supply, whereas $82.9 \%$ claimed access to public electricity supply. Cell phone appeared to be the major telecommunication means with $31.6 \%$ claiming access with $17.1 \%$ frequency of ownership.

Earth materials that are naturally occurring were used by the housing producers for foundation ( $38.1 \%$ naturally occurring, $19.3 \%$ stabilized), ground floor (60\%) and wall (53.3\% naturally occurring, $18.4 \%$ stabilized) as shown in Figure 3 . Concrete, a quintessential material was used for foundation by $25.6 \% ; 24.5 \%$ used it for the floor, while $37.1 \%$ reinforced it for lintel. Stone was more used in foundation (23.9\%) perhaps because it is naturally occurring than sandcrete blocks $(16.6 \%)$. More houses $(28.3 \%)$ used sandcrete blocks as wall. Wood was a prominent material in doors (72\%), noggins (86\%) and roof $(97.3 \%)$ including different types of windows- casement and louvers - for houses that had windows not covered with alternative materials like cloth, canvas, metal (corrugated or flat) sheets or metal grille. Corrugated zinc iron sheets as roof cover $(95.4 \%)$ was a common identity. 


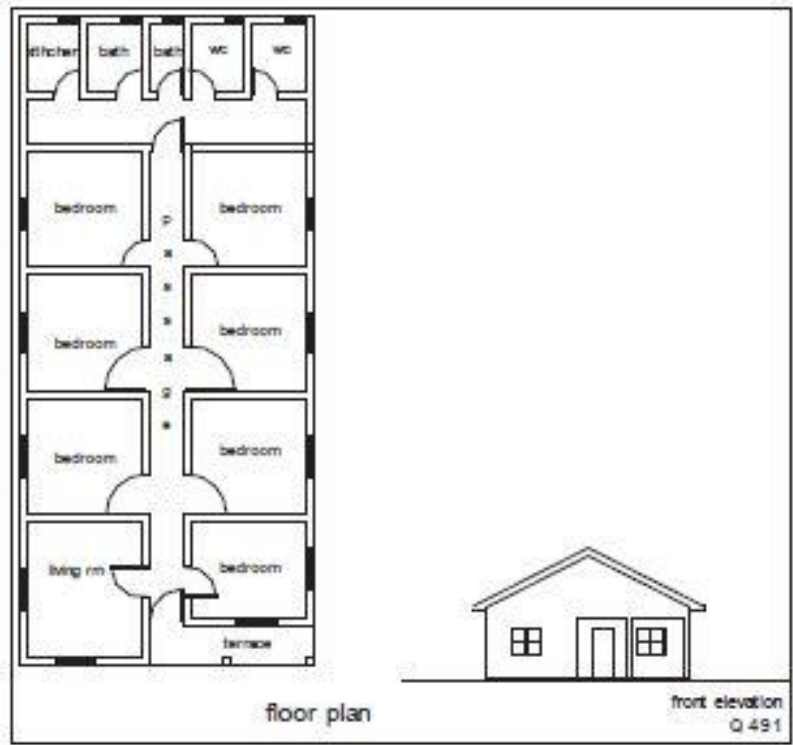

Figure 1: Plan of a Typical House in Ogbere showing Location of Service Spaces Source: (Jaiyeoba, 2011)

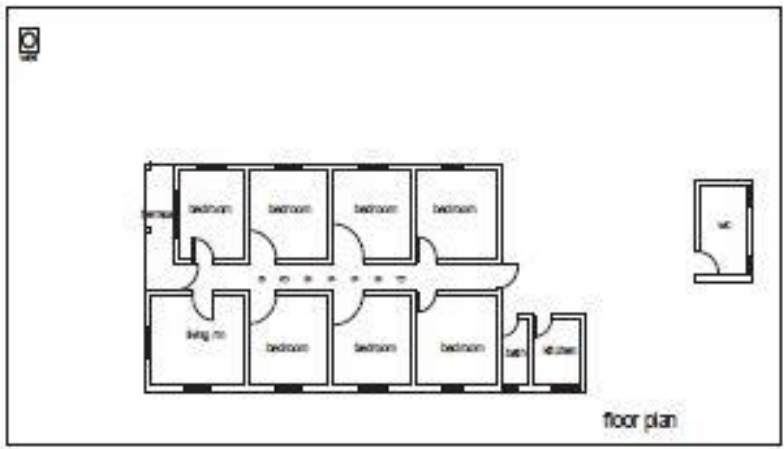

Figure 2: Layout of a Compound showing the Location of Services Source: (Jaiyeoba, 2011)

Affordability was a strong factor in their choice of materials though they were unwilling to acknowledge it perhaps because of self-esteem. They also wanted a material that was in vogue, acceptable and common to the city but not necessarily one used by a friend. In spite of their limited resources, in the Ogbere case study they were not looking for free or scavenged material. Even if, the material is cheap and not readily acceptable in the urban environment, they then consider 'presenting' the material as modern or in vogue to conform 
to other buildings around and other peoples taste. This explains their masking whatever walling material they use in cement/ sand plaster. The houses were in different stages of completion with less than one third (31.6\%) fully complete. Most houses have vehicular accessibility problem. The houses were produced more for family use. The indicator is that the number of rooms for the owner occupier had a positive correlation with the number of rooms built and a negative correlation with the rooms rented out. This is corroborated by the finding that the single family occupied house at $31.4 \%$ dominated; dual occupancy occurred in $15.6 \%$ of the houses, while 3 to 4 households occupied $37.7 \%$ of the houses. Renting outrooms was also not necessarily motivated by the need for money since personal income was not a significant predictor variable for renting out rooms among the low income people in Ogbere. Though pettytrading was the most common form of home based enterprise, it appeared that it was not done from shops because of the minimal number of shops in the area.

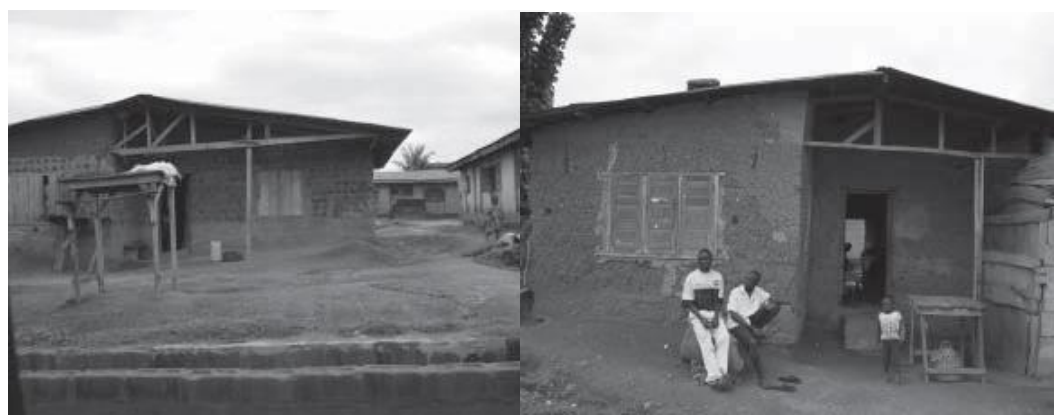

Figure 3: Buildings of Earth Material and Wood Casement Windows in Different Stages of Completion

Source: (Jaiyeoba, 2011)

The gradual or steady approach remained the only option considering the resources accessible to the producers in their alienated position and what they could negotiate for in everyday life from space. There was a wide range of 0 to 51 years for the time lag between buying land and starting construction. However, the mean time lag was 3.03 years with a median of 1 year. The modal group (29.8\%) actually commenced construction the same year land was bought. In fact, less than ten percent $(9.4 \%)$ had a time lag of more than 8 years before starting construction after buying the land. A considerable percentage of the Ogbere housing producers (61.5\%)moved in within three years of commencing construction; $12.1 \%$ in the same year, $19 \%$ after a year, $18.2 \%$ after two years and $12.3 \%$ after three years. The mean duration was 4.62 years and less than ten per cent (8.9\%) had not moved in by the $13^{\text {th }}$ year.

The everyday drop of resources made the buying of land, foundation and roofing to the most problematic stages since a lot of money was needed to be spent at once. Social network, day to day relations, informal contacts and indigenous knowledge contributed significantly to 
negotiating these problematic stages. Cash gifts from people they had strong and weak ties $(30.2 \%)$ were the highest contributor to financial resources in the production process. The others were children contribution (29.7\%); credit facility $(29.3 \%)$; personal income/savings (28.4\%); and family contribution (25.2\%) in a rating that was not mutually exclusive. For the housing producers, building up to the roof meant habitability and completion and once the perimeter doors and windows were taken care of, there was protection from the elements and 'unwanted' guests and their desire to have a house was satisfied. Ethically, it can be argued that all people are entitled to fundamental services for their houses: water supply, disposal of water including sewerage, provision of electricity, insulation or defence against extremes of weather as appropriate to the climate, rooms that ensure privacy, labour-saving devices in the kitchen and so on (Oliver, 2000). To speak of 'good design' being superior to bad design would have little meaning to a people to whom the balance of the desirable and the undesirable is an essential aspect of life (Griaule and Dieterlen, 1954). Therefore, for the low income, after habitability other stages - full services, ceiling, finishes and fencing - had to wait until resources from everyday life accrued to sufficiency to provide them. The residential activities of great value to low income people were sleeping, guest entertainment and social interaction 'internally'; bathing, cooking, and toileting; in that order as back of the house activities. The sharing of services was well tolerated even if they are not more than 1 or at most 2 in the house.

The Ogbere representational space is therefore, a reflection of the housing quality that the low income people can negotiate in the abstract space of Ibadan City, Nigeria.

\section{Conclusion}

The housing quality attained even if housing experts and urbanists considers it substandard is the product of a long struggle and negotiation in an environment of nonprovision. It is a reflection of their aspiration to live and contribute to individual, family and common quality of life in the urban environment. In this context, they have deployed the motivation derived from indigenous knowledge acquired from living in the family house and reproduced in informal vocations and social capital to the production of housing. In the process and product, they displayed resources that may be supported or enhanced; operated at the margin of space of representation (expectations of experts, institutions and public authorities) and representational space (what is possible within what society allows them access); or simply the dynamism of housing quality in space and time. Therefore, it is necessary for policy experts to understand the totality of the social profile of low income people, the processes they adopt, and the different stages of the product in different social contexts to intervene in improving the housing quality of the majority in the urban environment.

\section{Acknowledgement}

I acknowledge with thanks the contribution of Professor Bayo Amole. 


\section{References}

Awofeso, P. (2010). One Out of Two Nigerians now Lives in a City: There are Many Problems but One Solution. World Policy Journal27:67

Boonyabancha, S. (2005). Baan Mankong: Going to Scale with "slum" and Squatter upgrading in Thailand. Environmentand Urbanization 17:21.

Butler, C. (2003). Law and the Social Production of Space. Ph.D thesis submitted to Faculty of Law, Griffith University, Queens land.

Griaule, M. \& Dieterlen, G. (1954). The Dogon. in C. Darryl Ford (ed) African Worlds. Oxford University press: London.

Jaiyeoba, E. B. (2011). Social Production of Private Low income Housing in Ogbere Ibadan. Saarbrucken: LAP LAMBERTAcademicPublishing.

Lefebvre, H. (1976). The Survival of Capitalism, Allison \& Busby: London. Lefebvre, H. (1991). The production of Space, Blackwell: Oxford.

Oliver, P. (2000). Ethics and Vernacular Architecture in Warwick Fox (ed) Ethics and the Built Environment, Routledge: London \& New York.

Roberts, I. (2000). Leceister Environment City: Learning How to Make Agenda 21, Partnerships and Participants Deliver. Environment and Urbanization. 12: 9.

Walker, A. (2001). The Social Context of Built form: the Case of Informal Housing Production in Mexico City. Working Paper No 114, Development and Planning Unit, University College, London. 